\title{
ANALISIS BRAND EQUITY \\ (KASUS PADA USAHA KULINER BAKSO MANDIRI JEMBER)
}

Vania Puspita Anggraeni ${ }^{1}$, Tanti Kustiari ${ }^{2}$, Muksin $^{3}$, Huda Ahmad Hudori ${ }^{4}$

Department of Agribusiness Management, Politeknik Negeri Jember 68101

${ }^{1}$ vaniapuspita21@gmail.com, ${ }^{2}$ tanti_kustiari@ polije.ac.id, ${ }^{3}$ muksin.paper@gmail.com, ${ }^{4}$ huda.hudori@ polije.ac.id ${ }^{3}$

\begin{abstract}
Along with the development of the era, the meatball culinary business is more and more easily found, so that the meatball culinary business competition is also increasingly competitive. The purpose of this study was to analyze the effect of brand awareness, brand loyalty, brand association, and perceived quality at Bakso Mandiri Jember Regency on brand equity. This study uses 100 populations that have been determined by previous researchers and calculated using the Slovin formula to find 50 samples as respondents from independent meatball consumers who filled out closed questionnaires with judgment sampling data collection methods. The results of the analysis and discussion that have been carried out in this study, it can be concluded that all independent variables consisting of brand awareness, brand loyalty, brand associations, and perceived quality simultaneously affect the dependent variable brand equity (brand equity) through the $F$ test. $t$ test only variable brand loyalty that has a significant effect on brand equity.
\end{abstract}

Keywords: Brand Equity, Brand Awareness, Brand Loyalty, Brand Association, Quality Perception

\begin{abstract}
Abstrak
Seiring perkembangan zaman usaha kuliner bakso semakin banyak dan mudah ditemui, sehingga persaingan usaha kuliner bakso juga semakin kompetitif. Tujuan dari penelitian ini adalah menganalisis pengaruh kesadaran merek, kesetiaan merek, asosiasi merek, dan kualitas yang dirasakan pada Bakso Mandiri Kabupaten Jember terhadap brand equity. Penelitian ini menggunakan 100 populasi yang telah ditetapkan peneliti sebelumnya dan dihitung menggunakan rumus slovin hingga menemukan 50 sampel sebagai responden dari konsumen bakso mandiri yang mengisi kuisioner tertutup dengan metode pengambilan data judgment sampling. Hasil analisis dan pembahasan yang telah dilakukan pada penelitian ini, dapat disimpulkan bahwa semua variabel bebas yang terdiri dari kesadaran merek, kesetiaan merek, asosiasi merek, dan kualitas yang dirasakan berpengaruh serempak pada variabel terikat brand equity (ekuitas merek) melalui uji F. Namun pada uji t hanya variabel kesetiaan merek yang berpengaruh signifikan terhadap brand equity.
\end{abstract}

Kata kunci: Brand Equity, Kesadaran Merek, Kesetiaan Merek, Asosiasi Merek, Kualitas yang dirasakan

\section{Pendahuluan}

Bakso merupakan makanan yang cukup populer dan digemari di Indonesia. Penyajian yang sesuai dengan lidah orang Indonesia dan cita rasa yang menggugah selera, membuat eksistensi bakso masih bertahan hingga saat ini. Banyak sekali orang yang ingin meraup keuntungan melalui bisnis usaha bakso. Maka tidak heran jika beraneka ragam inovasi produk bakso telah dilakukan untuk menarik minat konsumen dan bertahan di tengah persaingan.

Selain inovasi produk, memperhatikan brand equity atau ekuitas merek juga penting dilakukan oleh pemilik usaha untuk memperkuat usaha bakso yang sedang dijalankan. Menurut Adam (2018) brand equity atau ekuitas merek dapat menambah atau mengurangi nilai produk atau jasa di mata konsumen, karena ekuitas merek tersebut dapat membantu konsumen menafsirkan, memproses dan menyimpan informasi dalam jumlah yang besar tentang produk atau jasa yang dijanjikan merek.
Menurut Aaker dalam Adam (2018) brand equity atau kekuatan merek akan semakin tinggi seiring tingginya dimensi brand equity atau ekuitas merek yang meliputi kesadaran merek, kesetiaan merek, kesan kualitas, asosiasi merek, dan aset lainnya seperti hak paten, stempel dagang, saluran distribusi dan lain- lain.

Menurut Adam (2018) kesadaran merek adalah kesanggupan konsumen untuk menggali atau mengingat kembali, bahwa suatu merek merupakan bagian dari kategori produk tertentu atau dengan perkataan lain adalah seberapa kuat suatu merek tertanam dalam benak atau ingatan konsumen.

Menurut Adam (2018) kesetiaan merek adalah kesetiaan pelanggan terhadap suatu merek tertentu. Loyalitas merek berbeda dengan dimensi-dimensi yang lain karena dimensi ini hanya dapat terjadi melalui pengalaman menggunakan produk atau jasa yang diwakili merek tersebut oleh pelanggan. 
Menurut Adam (2018) asosiasi merek adalah segala hal yang berkaitan dengan ingatan tentang sebuah merek. dirasakan adalah persepsi konsumen terhadap bakso mandiri Kabupaten Jember, yang dapat keseluruhan kualitas atau keunggulan suatu produk atau mempengaruhi citra produk hingga volume penjualan. jasa dan bila kesan kualitas meningkat, maka elemen kesan-kesan konsumen yang lainpun pada umumnya 2.2 akan meningkat.

Bakso Mandiri yang berada di Kabupaten Jember, tepatnya di daerah Desa Tanjungrejo kecamatan wuluhan, merupakan salah satu usaha kuliner bakso wilayah generalisir yang terdiri atas objek atau subjek yang memiliki nama besar di telinga masyarakat di yang mempunyai kuantitas dan karakteristik tertentu antara beberapa usaha kuliner bakso yang ada di yang ditetapkan oleh peneliti untuk dipelajari dan sekitarnya. Bakso mandiri juga menjadi salah satu kemudian ditarik kesimpulannya. Penelitian ini usaha kuliner yang cukup lama dan mampu menggunakan 100 populasi dari konsumen bakso mempertahankan eksistensinya mandiri.

Fenomena bisnis yang terjadi adalah ketika Bakso Menurut Sugiyono (2015) Sampel penelitian Mandiri dapat mempertahankan kestabilan usaha di adalah bagian dari jumlah dan karakteristik yang tengah persaingan bisnis yang melibatkan banyak dimiliki oleh populasi tersebut. Penelitian ini merek kuliner bakso dengan nama besarnya. Bahkan menggunakan 50 sampel yang telah dihitung lokasi usaha yang ada di sekitar pedesaan juga tidak menggunakan rumus slovin sebagi berikut: terlalu ramai seperti di kota dan promosi yang dilakukan juga tidak secara besar-besaran melalui media sosial.

Berdasarkan latar belakang yang sudah dijelaskan maka perlu dilakukan penelitia untuk menganalisis seberapa kuat brand equity atau ekuitas merek pada produk Bakso Mandiri yang ada di Kabupaten Jember melalui variabel brand equity atau ekuitas merek yang

telah dijelaskan sebelumnya. Sehingga, untuk e = Tingkat Kesalahan (10\%) merealisasikan penelitian tersebut peneliti akan mengangkat judul Analisis Brand Equity (Studi Kasus pada Bakso Mandiri Kabupaten Jember

Penelitian ini diharapkan dapat diimplementasi dalam melakukan pemasaran sebuah produk di tengah masyarakat secara kompetitif. Selain itu, dengan melakukan penelitian tentang analisis brand equity atau ekuitas merek, peneliti berharap agar hasil penelitian ini dapat menjadi pertimbangan dalam menyusun strategi pemasaran dengan memperhatikan variabel brand equity atau ekuitas merek yang berpengaruh terhadap minat beli konsumen.

\section{Metode Penelitian}

\subsection{Rancangan Penelitian}

Penelitian ini dilakukan dengan menggunakan metode penelitian deskriptif dan korelasi. Menurut Arikunto dalam Suharyani (2015) penelitian deskriptif dimaksudkan untuk menggambarkan apa adanya suatu variabel, gejala atau keadaan. Menurut Ameliawaty dan Halilah (2017) metode analisis korelasi sederhana ini digunakan untuk mengetahui adanya hubungan antar variabel. Data yang digunakan dalam penelitian ini juga berupa data primer dan sekunder yang berasal dari lingkungan eksternal.

$$
\mathrm{n}=\frac{N}{1+N(e)^{2}}
$$

Keterangan :

$\mathrm{n}=$ Jumlah Sampel

$\mathrm{N}=$ Jumlah Populasi

2.2.2 Teknik Pengambilan Sampel

Penelitian ini menggunakan teknik judgment sampling dan banyaknya sampel yang diambil dihitung menggunakan rumus slovin dan telah ditetapkan kriteria terlebih dahulu oleh peneliti.

\subsection{Skala Pengukuran}

Menurut Malhotra dalam Lisa dkk (2020) Skala likert adalah suatu skala pengukuran dengan kategori respon yang memiliki variasi dari sangat tidak setuju sampai ke sangat setuju, yang mengharuskan responden untuk mengindikasikan sebuah tingkatan persetujuan atau pertidaksetujuan terhadap serangkaian pernyataan yang berhubungan dengan objek stimulan.

\subsection{Variabel Penelitian}

Menurut Sugiyono (2018) variabel penelitian adalah suatu atribut atau sifat atau nilai dari orang, obyek, atau kegiatan yang mempunyai variasi tertentu yang ditetapkan oleh peneliti untuk dipelajari dan kemudian ditarik kesimpulannya.

\subsection{Instrumen Penelitian}




\section{Menurut Sugiyono (2016) instrumen penelitian 3. Hasil dan Pembahasan}

adalah alat yang digunakan untuk mengukur fenomena alam maupun sosial yang diamati.

Rangkaian hasil penelitian berdasarkan urutan/susunan logis untuk membentuk sebuah cerita. Isinya menunjukan fakta/data dan jangan diskusikan hasilnya. Dapat menggunakan Tabel dan Angka tetapi

\subsection{Lokasi dan Waktu Penelitian} Penelitian ini dilaksanakan di usaha Bakso tidak menguraikan secara berulang terhadap data yang
diri Desa Tanjungrejo, Kecamatan Wuluhan, sama dalam gambar, tabel dan teks. Untuk lebih Kabupaten Jember dalam kurun waktu 5 bulan memperjelas uraian, dapat mengunakan sub judul.

Pembahasan adalah penjelasan dasar, hubungan dan

\subsection{Prosedur Pengumpulan Data} generalisasi yang ditunjukkan oleh hasil. Uraiannya

Pertama, melakukan wawancara dengan pemilik menjawab pertanyaan penelitian. Jika ada hasil yang usaha. Kedua, melakukan pengambilan data dengan meragukan maka tampilkan secara objektif. memberikan kuisioner kepada konsumen. Ketiga, melakukan dokumentasi

3.1. Hasil Penlitian

\subsection{Uji Validitas dan Reliabilitas}

2.8.1 Uji Validitas

3.1.1 Frekuensi Usia dan Jenis Kelamin Responden Penelitian ini menunjukkan bahwa 50 responden Menurut Suharyani (2015) Uji Validitas adalah Jang terlibat terdiri dari 14 orang laki-laki (28\%) dan untuk melihat kecermatan alat ukur yaitu mengukur apa Konsumen yang memiliki usia dalam rentang 19-23 yang akan diukur. Valid berarti instrumen tersebut tahun terdiri dari dari 5 orang laki-laki (10\%) dan 27 dapat digunakan untuk mengukur apa yang hendak perempuan (54\%). Konsumen yang memiliki usia diukur.

dalam rentang 24-28 tahun terdiri dari 2 orang laki-laki

Menurut Priyatno (2017) dasar pengambilan (4\%) dan 2 orang perempuan (4\%). Konsumen yang keputusan suatu item valid atau tidak dengan cara memiliki usia dalam rentang 29-33 tahun terdiri dari 1 mengkorelasikan antara skor butir dengan skor total, orang laki-laki (2\%) dan 1 orang perempuan (2\%). kemudian untuk uji signifikansi dilakukan dengan Konsumen yang memiliki usia dalam rentang 34-38 menggunakan $r$ tabel pada tingkat signifikani 0,05 tahun terdiri dari 1 orang perempuan saja (2\%). dengan uji 2 sisi.

\subsubsection{Uji Reliabilitas} dilakukan untuk menguji apakah jawaban dari (2\%). Konsumen yang memiliki usia dalam rentang 49responden konsisten atau labil.

\subsection{Metode Analisis Data}

\subsubsection{Analisis Linier Berganda}

Menurut Palupiningtyas dan Aryaningtyas (2017) Konsumen yang memiliki usia dalam rentang 39-43 tahun terdiri 4 orang laki-laki $(8 \%)$ dan 3 orang perempuan $(6 \%)$. Konsumen yang memiliki usia dalam analisis linier berganda digunakan untuk menguji memiliki tujuan untuk mengetahui tingkat kevalidan pengaruh lebih dari satu variabel bebas terhadap pertanyaan yang digunakan dalam kuisioner sebagai variabel terikat.

\subsubsection{Analisis Koefisien Determinasi} yang terlibat sebanyak 50 orang dengan kriteria yang telah ditentukan oleh peneliti sebagai upaya untuk

Menurut Sari dkk (2015) koefisien determinasi memenuhi tujuan penelitian. Ketentuan dalam (R2) dapat didefinisikan sebagai seberapa besar pelaksanaan uji validitas agar pertanyaan dapat kemampuan variabel bebas dalam menghitung besarnya dikatakan valid adalah ketika $r$ hitung $>r$ korelasi dan kontribusi varian dari variabel terikatnya.

angka signifikansi lebih kecil dari angka signifikansi 0,05 .

\subsubsection{Uji F}

Uji validitas pada penelitian yang melibatkan 50

Menurut Sari dkk (2015), uji F atau uji serempak konsumen Bakso Mandiri sebagai responden dapat digunakan untuk melihat bagaimana pengaruh variabel dikatakan valid karena nilai $r$ hitung $>r$ tabel dan nilai bebas secara simultan terhadap variabel terikatnya. signifikansi lebih kecil dari angka signifikansi 0,05

\subsubsection{Uji t}

Menurut Ghozali dalam Lisa dkk (2020), uji t merupakan metode pengujian dalam statistik digunakan
untuk menguji besarnya pengaruh semua variabel bebas secara parsial terhadap variabel terikat.

\subsubsection{Hasil Uji Reliabilitas}

Setelah melakukan uji validitas, maka langkah selanjutnya adalah melakukan uji reliabilitas. Pelaksanaan uji reliabilitas ini bertujuan untuk mengetahui konsistensi pada setiap item pertanyaan 
yang ada pada instrumen penelitian. Metode yang digunakan dalam pelaksanaan uji reliabilitas di penelitian ini adalah rumus cronbach's alpha. Suatu instrumen penelitian dikatakan reliable jika nila Suatu instrumen penelitian (kuesioner) dapat dikatakan reliable jika nilai $\alpha$ yang dihasilkan dari data kuesioner lebih besar dibandingan dengan nilai $\alpha$ yang telah ditentukan.

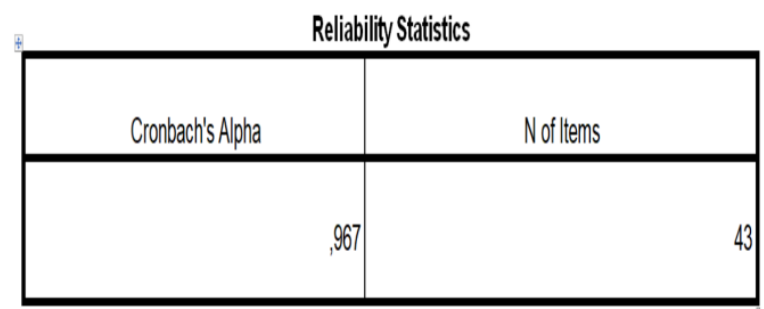

Hasil pengolahan data uji reliabilitas menunjukkan bahwa nilai Cronbach's alpha $(\alpha)$ sebesar 0,967 dengan 43 item pertanyaan yang digunakan dalam kuisioner penelitian ini. Sehingga setiap item pertanyaan dapat dikatakan reliable karena nilai Cronbach's alpha $(\alpha)$ lebih besar dari nilai krisis reliabilitas 0,60.

\subsubsection{Hasil Analisis Regresi Linier Berganda}

Pelaksanaan analisis linier berganda pada 50 responden konsumen Bakso Mandiri Jember bertujuan untuk menjelaskan pengaruh variabel bebas terhadap variabel terikat. Pada penilitian ini, variabel bebas terdiri dari Kesadaran Merek (X1), Kesetiaan Merek (X2), Asosiasi Merek (X3), dan Kualitas yang dirasakan (X4). Sementara variabel terikat pada penelitian ini adalah brand equity atau ekuitas merek (Y). Berdasarkan perhitungan analisis linier berganda diperolah hasil sebegai berikut:

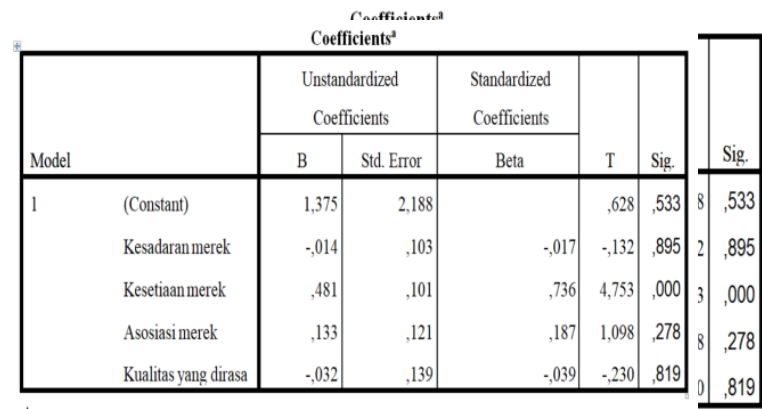

Berdasarkan hasil pengolahan data pada tabel di atas, diperolah persamaan regresi linier berganda sebagai berikut:

$\mathrm{Y}=1,375-0,014 \mathrm{X} 1+0,481 \mathrm{X} 2+0,133 \mathrm{X} 3-0,032 \mathrm{X} 4$ $+\mathrm{e}$

Persamaan di atas dapat di jelaskan sebagai berikut:

1. Nilai konstanta sebesar 1,375

Nilai konstanta yang bernilai positif 1,375 memiliki kesadaran merek (X1), kesetiaan merek (X2), asosiasi arti bahwa apabila variabel kesadaran merek (X1), merek (X3), dan kualitas yang dirasakan (X4) sebesar
Kesetiaan merek (X2), Asosiasi merek (X3), Persepsi merek (X4) bernilai 0 maka nilai brand equity atau ekuitas merek sebesar 1,375

2. Nilai koefisien kesadaran merek (X1) sebesar 0,014

Nilai koefisien kesadaran merek (X1) yang bernilai negatif sebesar $-0,014$ memiliki arti bahwa setiap adanya peningkatan 1 satuan pada kesadaran merek maka akan menurunkan brand equity atau ekuitas merek pada Bakso Mandiri Jember sebesar -0,014

3. Nilai koefisien kesetiaan merek (X2) sebesar 0,481

Nilai koefisien kesetiaan merek (X2) yang bernilai positif sebesar 0,481 memiliki arti bahwa setiap adanya peningkatan 1 satuan pada kesetiaan merek maka akan menaikkan brand equity atau ekuitas merek pada Bakso Mandiri Jember sebesar 0,481

4. Nilai koefisien asosiasi merek (X3) sebesar 0,133

Nilai koefisien asosiasi merek (X3) yang bernilai positif sebesar 0,133 memiliki arti bahwa setiap adanya peningkatan 1 satuan pada asosiasi merek maka akan menaikkan brand equity atau ekuitas merek pada Bakso Mandiri Jember sebesar 0,133

5. Nilai koefisien kualitas yang dirasakan (X4) sebesar $-0,032$

Nilai koefisien kualitas yang dirasakan (X4) yang bernilai negatif sebesar -0,032 memiliki arti bahwa setiap adanya peningkatan 1 satuan pada kualitas yang dirasakan maka akan menurunkan brand Jember sebesar $-0,032$

\subsubsection{Hasil Analisis Koefisien Determinasi $\left(\mathrm{R}^{2}\right)$}

Perhitungan koefisien determinasi dilakukan untuk mengetahui besarnya pengaruh antara variabel bebas yang terdiri dari kesadaran merek (X1), kesetiaan merek (X2), asosiasi merek (X3), kualitas yang dirasakan (X4), terhadap brand equity atau ekuitas merek (Y). Hasil dari perhitungan koefisien determinasi melalui pengolahan data adalah sebagai berikut:

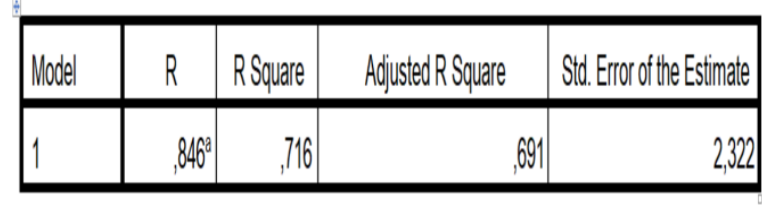

Tabel tersebut menunjukkan nilai koefisien determinasi adjusted R2 sebesar 0,691 atau 69,1\%. Maka, hal ini dapat dijelaskan bahwa variabel terikat (Y) brand equity atau ekuitas merek Bakso Mandiri dipengaruhi variabel bebas yang terdiri dari equity atau ekuitas merek pada Bakso Mandiri 
$69,1 \%$. Sedangkan 30,9\% lainnya disebabkan oleh faktor lain yang tidak dilibatkan pada penelitian ini

Hasil perhitungan koefisien determinasi sebesar 0,691 atau $69,1 \%$ menunjukkan pengaruh variabel bebas yang terdiri kesadaran merek (X1), kesetiaan merek (X2), asosiasi merek (X3), dan kualitas yang dirasakan (X4) dengan variabel terikat (Y) brand equity atau ekuitas merek termasuk kategori kuat. Karena nilai koefisien determinasi yang menunjukkan hubungan variabel bebas dan terikat semakin kuat jika mendekati satu. Hasil penelitian ini dikategorikan kuat karena besarnya korelasi (R) terletak diantara 0,60-0,799.

\subsubsection{Uji F}

Uji $\mathrm{F}$ dilakukan dalam sebuah penelitian untuk mengetahui pengaruh variabel bebas yang terdiri kesadaran merek (X1), kesetiaan merek (X2), asosiasi merek (X3), kualitas yang dirasakan (X4) secara serempak dan signifikan terhadap variabel terikat (Y) brand equity atau ekuitas merek. Ketentuan dalam pelaksanaan uji $\mathrm{F}$ agar variabel bebas dapat dikatakan berpengaruh secara serempak dan signifikan adalah ketika nilai Fhitung lebih besar dari Ftabel dan angka signifikansi lebih kecil dari angka signifikansi 0,05. Perhitungan uji t yang telah dilaksanakan, diperoleh hasil sebagai berikut:

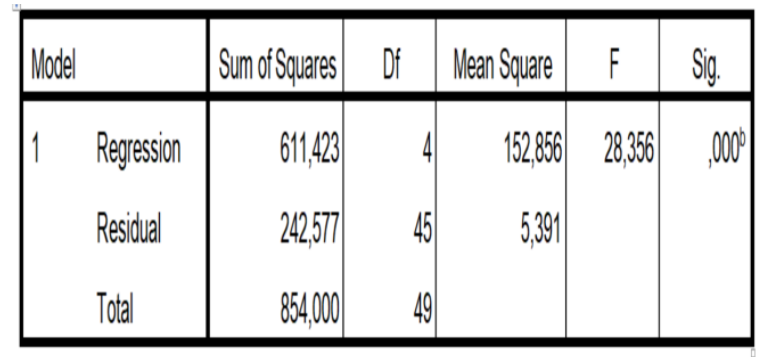

Tabel menunjukkan bahwa Fhitung yang bernilai 28,356 lebih besar daripada Ftabel yang bernilai 2,58 dan nilai signifikansi sebesar 0,000 berada dibawah nilai signifikansi 0,05 sehingga dapat disimpulkan bahwa semua variabel bebas yang terdiri dari kesadaran merek (X1), kesetiaan merek (X2), asosiasi merek (X3), kualitas yang dirasakan (X4) berpengaruh secara serempak dan signifikan terhadap brand equity atau ekuitas merek pada Bakso Mandiri Jember.

\subsubsection{Uji t}

Uji t yang dilakukan pada penelitian ini memiliki tujuan untuk membuktikan adanya pengaruh secara parsial atau individu dari variabel bebas yang terdiri dari kesadaran merek (X1), kesetiaan merek (X2), asosiasi merek (X3), kualitas yang dirasakan (X4) terhadap brand equity atau ekuitas merek. Ketentuan dalam pelaksanaan uji $\mathrm{t}$ agar variabel bebas dapat dikatakan berpengaruh secara signifikan adalah ketika nilai thitung lebih besar dari ttabel dan angka signifikansi lebih kecil dari angka signifikansi 0,05.
Dari perhitungan uji t yang telah dilaksanakan, diperoleh hasil sebagai berikut:

\begin{tabular}{|c|c|c|c|c|c|c|}
\hline \multirow[b]{2}{*}{ Model } & & \multicolumn{2}{|c|}{$\begin{array}{l}\text { Unstandardized } \\
\text { Coefficients }\end{array}$} & \multirow{2}{*}{$\begin{array}{c}\begin{array}{c}\text { Standardized } \\
\text { Coefficients }\end{array} \\
\text { Beta }\end{array}$} & \multirow[b]{2}{*}{ T } & \multirow[b]{2}{*}{ Sig. } \\
\hline & & B & Std. Error & & & \\
\hline \multirow[t]{5}{*}{1} & (Constant) & 1,375 & 2,188 & & ,628 &, 533 \\
\hline & Kesadaran merek & -014 & 103 & -017 & -132 & \\
\hline & Kesetiaan merek & , 481 & ,101 &, 736 & 4,753 & \\
\hline & Asosiasimerek & 133 & 121 & 187 & 1,098 &, 218 \\
\hline & Kualitas yang dirasa & -032 & ,139 & -039 & -230 & \\
\hline
\end{tabular}

Dari tabel tersebut dapat dijelaskan sebagai berikut:

1. Variabel kesadaran merek (X1) memiliki nilai thitung sebesar -0,132 menunjukkan bahwa thitung lebih kecil dari ttabel sebesar 2,01410 dengan nilai signifikansi 0,895 yang berarti lebih besar dari tarif signifikansi 0,05 (5\%). Hal ini menjelaskan bahwa variabel kesadaran merek (X1) tidak berpengaruh secara signifikan terhadap Brand Equity atau Ekuitas Merek (Y) Bakso Mandiri, Jember.

2. Variabel kesetiaan merek (X2) memiliki nilai thitung sebesar 4,753 menunjukkan bahwa thitung lebih besar dari ttabel sebesar 2,01410 dengan nilai signifikansi 0,000 yang berarti lebih kecil dari tarif signifikansi 0,05 (5\%). Hal ini menjelaskan bahwa variabel kesetiaan merek (X2) berpengaruh secara signifikan terhadap Brand Equity atau Ekuitas Merek (Y) Bakso Mandiri, Jember.

3. Variabel asosiasi merek (X3) memiliki nilai thitung sebesar 1,098 menunjukkan bahwa thitung lebih kecil dibandingkan dari ttabel sebesar 2,01410 dengan nilai signifikansi 0,278 yang berarti lebih besar dibandingkan angka tarif signifikansi 0,05 (5\%). Hal ini menjelaskan bahwa variabel asosiasi merek (X3) tidak berpengaruh secara signifikan terhadap Brand Equity atau Ekuitas Merek (Y) Bakso Mandiri, Jember.

4. Variabel kualitas yang dirasakan (X4) memiliki nilai thitung sebesar -0,230 menunjukkan bahwa thitung lebih kecil dibandingkan dari ttabel sebesar 2,004 dengan nilai signifikansi 0,819 yang berarti lebih besar dibandingkan angka tarif signifikansi $0,05(5 \%)$. Hal ini menjelaskan bahwa variabel kualitas yang dirasakan (X4) tidak berpengaruh secara signifikan terhadap Brand Equity atau Ekuitas Merek (Y) Bakso Mandiri, Jember.

\subsection{Pembahasan}

Hasil penelitian yang dilakukan tentang kesadaran merek (X1), kesetiaan merek (X2), asosiasi merek (X3), kualitas yang dirasakan (X4) terhadap variabel terikat (Y) brand equity atau ekuitas merek Bakso Mandiri Jember memperoleh data sebagai berikut:

3.2.1 Pengaruh Kesadaran Merek, Kesetiaan Merek, Asosiasi Merek, dan Kualitas yang dirasakan 


\section{Secara Serempak Terhadap Brand Equity atau a. Asosiasi Merek}

Ekuitas Merek

Berdasarkan hasil pengujian pada variabel

Hasil analisis linier berganda menunjukkan nilai asosiasi merek (X3) memiliki nilai thitung sebesar positif dengan memberikan penjelasan selaras antara 1,098 menunjukkan bahwa thitung lebih kecil variabel bebas dan variabel terikat. Pada hasil uji F dibandingkan dari ttabel sebesar 2,01410 dengan nilai menunjukkan nilai Fhitung sebesar 28,356 dan nilai signifikansi 0,278 yang berarti lebih besar Ftabel sebesar 2,58. Sehingga nilai Fhitung lebih besar dibandingkan angka tarif signifikansi 0,05 (5\%). Hal ini dari pada Ftabel (Fhitung > Ftabel) dengan nilai menjelaskan bahwa variabel asosiasi merek (X3) tidak signifikansi sebesar 0,000 yang berada di bawah nilai berpengaruh secara signifikan terhadap brand equity signifikansi Fhitung sebesar 0,05. Dari hasil atau ekuitas merek (Y) Bakso Mandiri, Jember.

perhitungan tersebut dapat disimpulkan bahwa Hasil dari penelitian terhadap 50 responden yang kesadaran merek (X1), kesetiaan merek (X2), asosiasi menunjukkan bahwa asosiasi merek tidak berpengaruh merek (X3), kualitas yang dirasakan (X4) berpengaruh signifikan, artinya perubahan asosiasi merek tidak serempak dan signifikan terhadap variabel terikat $(\mathrm{Y})$ menunjukkan pengaruh yang besar terhadap brand brand equity atau ekuitas merek Bakso Mandiri Jember. equity atau ekuitas merek. Dari 10 pertanyaan yang mendasari 5 indikator asosiasi merek yaitu manfaat,

3.2.2 Faktor Brand Equity yang Berpengaruh Secara gaya hidup, kredibilitas, produk inovatif, dan citra Signifikan merek, sebagian besar 50 responden menunjukkan

Hasil perhitungan menunjukkan bahwa variabel bahwa konsumen Bakso Mandiri kurang menangkap yang berpengaruh secara signifikan adalah variabel identitas produk yang melekat pada Bakso Mandiri. kesetiaan merek (X2) dengan nilai thitung sebesar Identitas itu meliputi manfaat yang melekat pada 4,753. Hal tersebut menunjukkan bahwa thitung lebih produk dan gaya hidup yang digambarkan dalam besar dari ttabel 2,01410 dengan nilai signifikansi konsep produk. Sehingga konsumen kurang bisa 0,000 yang berarti lebih kecil dari tarif signifikansi 0,05 menggambarkan atau menghubungkan kategori suatu $(5 \%)$. produk ketika disebutkan nama Bakso Mandiri seperti

Hasil penelitian yang dilakukan pada 50 definisi asosiasi merek itu sendiri. Selain itu, menu responden menunjukkan bahwa kesetiaan merek yang diberikan oleh Bakso Mandiri juga tidak berpengaruh signifikan, artinya jika terjadi perubahan memberikan banyak menu dan cenderung seperti bakso pada kesetiaan merek, maka akan menimbulkan pada umumnya, yaitu varian urat dan halus. Sehingga pengaruh atau perubahan besar terhadap brand equity konsumen sebagian besar menjawab bahwa Bakso atau ekuitas merek Bakso Mandiri. Dari 10 pertanyaan Mandiri kurang inovatif dalam persaingan kuliner yang mendasari 4 indikator yaitu komitmen, bakso setempat yang memberikan suguhan menu rekomendasi, kebiasaan memilih, dan kepuasan, beragam. Dari menu yang dinilai konsumen kurang menunjukkan bahwa konsumen Bakso Mandiri inovatif, akan menyebabkan penurunan brand equity sebagian besar bersedia untuk berkomitmen melakukan atau ekuitas merek karena konsumen tidak menemukan pembelian hingga masa mendatang secara berulang keunggulan produk untuk menguatkan merek Bakso meskipun banyak pesaing kuliner bakso yang semakin Mandiri dalam ingatannya. Meski konsumen tetap kompetitif. Adanya komitmen yang dilakukan oleh mengakui bahwa citra dan kredibilitas Bakso Mandiri konsumen Bakso Mandiri maka akan menanamkan baik, akan tetapi hal itu belum cukup menambah brand kekuatan merek melalui kesetiaan merek secara equity atau ekuitas merek Bakso Mandiri secara signifikan. Karena ditengah persaingan yang kompetitif signifikan karena para kompetitor usaha bakso membutuhkan komitmen dari konsumen untuk menjaga setempat juga memiliki kualitas atau kredibilitas yang eksistensi Bakso Mandiri agar brand equity atau ekuitas baik di mata konsumen.

merek terus meningkat. Selain itu, konsumen Bakso

Mandiri juga bersedia merekomendasikan kepada orang b. Kesadaran Merek

lain untuk memilih Bakso Mandiri yang sudah menjadi Hasil pengujian pada variabel kesadaran merek pilihan berkelanjutan. Karena menurut konsumen, menunjukkan bahwa variabel kesadaran merek (X1) produk Bakso Mandiri telah memberi kepuasan. Dari memiliki nilai thitung sebesar $-0,132$ menunjukkan kepuasan itu pula brand equity atau ekuitas merek bahwa thitung lebih kecil dari ttabel sebesar 2,01410 Bakso Mandiri tercipta karena dapat meningkatkan dengan nilai signifikansi 0,895 yang berarti lebih besar nilai produk Bakso Mandiri di mata konsumen. Selain dari tarif signifikansi 0,05 (5\%). Hal ini menjelaskan itu secara tidak langsung dengan adanya rekomendasi bahwa variabel kesadaran merek (X1) tidak yang dilakukan konsumen kepada orang lain maka akan berpengaruh secara signifikan terhadap brand equity menambah brand equity atau ekuitas Bakso Mandiri di atau ekuitas merek (Y) Bakso Mandiri, Jember.

tengah masyarakat.

Hasil perhitungan tersebut di dasarkan pada 3.2.3 Faktor Brand Equity yang Tidak Berpengaruh kuisioner tertutup yang diberikan kepada 50 responden Secara Signifikan konsumen bakso Mandiri Jember. Dari 8 pertanyaan 
yang didasari 4 indikator, yaitu mengenali merek, kualitas hampir sama. Mengingat tempat Bakso mengingat merek, ciri khas, dan mengenali varian, Mandiri juga berada di daerah pedesaan. Dengan menunjukkan bahwa pengenalan merek Bakso Mandiri demikian kualitas dan kehandalan Bakso Mandiri yang berada di puncak pikiran atau top of mind karena Bakso baik tidak berpengaruh signifikan terhadap kenaikan Mandiri sudah berdiri lama di sekitar lokasi tersebut. brand equity atau ekuitas merek.

Pengenalan merek Bakso Mandiri yang baik juga

menyebabkan merek Bakso Mandiri mudah diingat 3.2.4 Variabel yang berpengaruh dominan terhadap oleh konsumen. Selain menjadi usaha kuliner bakso yang berdiri cukup lama, nama merek yang mudah brand equity (ekuitas merek)

dihapal dan mudah diucapkan, juga menjadi penyebab variabel bebas, dapat disimpulkan bahwa variabel yang merek Bakso Mandiri mudah diingat. Namun, karena berpengaruh secara dominan pada ekuitas merek atau Bakso Mandiri jarang melakukan promosi baik secara Brand Equtiy adalah kesetiaan merek (X2). Karena offline atau online, konsumen kurang mengenali varian nilai thitung kesetian merek yang bernilai 4,753 lebih yang ditawarkan karena kekurangan informasi produk besar dari ttabel yang bernilai 2,01410 dan merupakan untuk referensi pemilihan produk. Selain itu, sebagian nilai thitung paling tinggi diantara variabel lainnya.

besar konsumen juga berpendapat bahwa ciri khas Pesaing Bakso Bakso Mandiri memiliki nama Bakso Mandiri kurang dikenali karena selain varian yang terkenal di benak konsumen dan kualitas produk menu yang sedikit, sebagian besar tidak menemukan yang baik. Meskipun Bakso Mandiri adalah usaha perbedaan atau ciri khas pada tekstur atau bentuk Bakso yang cukup lama, tapi dapat dikatakan jika produkBakso Mandiri. Jadi, meskipun kategori pesaingnya ini mampu hadir dalam inovasi produk pengenalan merek dan mengingat merek baik, hal yang beraneka ragam dan promosi yang baik untuk tersebut tidak berpengaruh signifikan terhadap brand menyaingi Bakso Mandiri dalam hal peningkatan brand equity atau ekuitas merek karena sebagian besar equity atau ekuitas merek. Namun, Bakso Mandiri konsumen belum menemukan keunggulan atau ciri dapat menjaga eksistensi produk melalui kesetiaan khas Bakso Mandiri dan belum mengenali varian secara merek yang dijawab oleh konsumen melalui kuisoner keseluruhan. Dimana ciri khas dan pengenalan varian yang telah diberikan.

Bakso Mandiri dapat menggambarkan atau Kuisioner sebagian besar menunjukkan konsumen menanamkan merek Bakso Mandiri secara kuat berada pada kategori kebiasaan dan urutan kedua dibenak konsumen serta menambah nilai produk Bakso adalah komitmen. Sehingga hal tersebut dapat Mandiri.

c. Kualitas yang dirasakan berpengaruh besar pada brand equity atau ekuitas merek Bakso Mandiri yang memiliki banyak pesaing yang memiliki kualitas baik.

Berdasarkan hasil pengujian pada variabel kualitas yang dirasakan (X4) memiliki nilai thitung sebesar -0,230 menunjukkan bahwa thitung lebih kecil dibandingkan dari ttabel sebesar 2,004 dengan nilai 4.1 Kesimpulan

signifikansi 0,819 yang berarti lebih besar Berdasarkan hasil analisis dan pembahasan yang dibandingkan angka tarif signifikansi 0,05 (5\%). Hal ini telah dilakukan pada penelitian ini, dapat disimpulkan menjelaskan bahwa variabel kualitas yang dirasakan bahwa:

(X4) tidak berpengaruh secara signifikan terhadap 1. Kesetiaan merek dinyatakan berepengaruh brand equity atau ekuitas merek (Y) Bakso Mandiri, Jember.

Hasil penelitian terhadap 50 responden menunjukkan bahwa kualitas yang dirasakan tidak berpengaruh signifikan, artinya, perubahan yang terjadi pada kualitas yang dirasakan tidak menimbulkan perubahan atau pengaruh besar terhadap ekuitas merek Bakso Mandiri. Dari 9 pertanyaan yang mendasari 3 indikator pada kualitas yang dirasakan yaitu kualitas, kehandalan, dan daya tahan sebagian besar konsumen mengakui bahwa produk Bakso Mandiri memang berkualitas dan dapat diandalkan. Namun, untuk daya tahan produk sebagian besar konsumen berpendapat 4.2 kurang baik. Sebagian besar konsumen mengatakan 1 bahwa pemilihan produk juga dipengaruhi harga. Sehingga, meskipun kualitas dan kehandalan Bakso Mandiri baik, konsumen cenderung akan memilih produk lain dengan harga yang lebih murah dengan serempak dengan variabel lain dalam penelitian ini melalui perhitungan uji $\mathrm{F}$ dan berpengaruh secara signifikan terhadap brand equity atau ekuitas merek melalui uji t. Kesetian merek juga menjadi variabel yang berpengaruh dominan terhadap brand equity atau ekuitas merek dibanding variabel lain yang diteliti dalam penelitian ini. Konsumen mau berkomitmen melakukan pembelian berulang atau terbiasa meskipun banyak pesaing Bakso Mandiri yang tidak kalah berkualitas dengan harga murah.

\section{.2 Saran}

Sebaiknya bakso mandiri lebih memperhatikan bauran pemasaran agar produk bakso mandiri semakin diterima masyarakat. Sehingga diharapkan dapat meningkatkan volume penjualan 
bakso mandiri jember dan brand quity atau ekuitas merek semakin kuat karena didukung oleh variabel lain dalam mempengaruhi

2. Bauran pemasaran dapat dievaluasi dengan melakukan brainstorming atau riset pasar lebih lanjut sehingga dapat lebih memahami kebutuhan pasar untuk disesuaikan dengan produk bakso mandiri. Baik dalam proses produksi atau tahap pengembangan produk dalam usaha kuliner

\section{Daftar Rujukan}

[1] Adam, M. 2018. Manajemen Pemasaran Jasa. Bandung: Alfabeta

[2] Ameliawaty, R., Halilah, L. Pengaruh Brand Awareness Terhadap Consumer Decision Making The Influence Of Brand Awareness To Consumer Decision Making. Jurnal Riset Bisnis \& Investasi. Vol. 3 No. 2 Tahun 2017

[3] Lisa, H., Chairhany, S., Napratilora, M., Syahid, A., Ilyas, M. 2020. Analisis Brand Equity Terhadap Keputusan Pembelian (Studi Kasus Coffee Toffee Surabaya). Journal of Business and Banking. Vol 10 No. 1 Tahun 2020
Palupiningtyas, D., Aryaningtyas, A.T. 2017. Pengaruh Komponen Pembentukan Ekuitas Merek Terhadap Intensitas Pembelian Wingko Babad Merek/Cap "Kereta Api" Sebagai Oleh-Oleh Khas Kota Semarang. Jurnal Media Ekonomi dan Manajemen. Vol. 32 No. 1 Tahun 2017

[5] Priyatno. 2017. Panduan Praktis Olah Data Menggunakan SPSS. Yogyakarta: CV. Andi Offset

6] Sari, R.A.I., Dh, A.F., Fanani, D. 2015. Pengaruh Ekuitas Merek Terhadap Keputusan Pembelian (Survei pada Warga Temenggungan Sebagai Pelanggan Indomie RT 10 RW 01 Kelurahan Sukoharjo Kecamatan Klojen Kota Malang). Jurnal Administrasi Bisnis. Vol. 1 No. 1 Tahun 2015

[7] Sugiyono. 2015. Statistika Untuk Penelitian. Bandung: Alfabeta

[8] Sugiyono. 2016. Metode Penelitian Kuantitatif, Kualitatif, dan R\&D. Cetakan ke 23. Bandung: Alfabeta

[9] Sugiyono. 2018. Metode Penelitian Kuantitatif, Kualitatif, dan R\&D. Bandung: Alfabeta

[10] Suharyani, K. 2015. Pengaruh Ekuitas Merek Terhadap Keputusan Pembelian Produk Minuman Teh Botol Sosro Pada Mahasiswa Jurusan Pendidikan Ekonomi Undiksha. Jurnal Jurusan Pendidikan Ekonomi. Vol 5 No. 1 Tahun 2015 